\title{
Risk Management Implementation Planning
}

\author{
(Case Study on the Philosophy of MSMEs Café)
}

\author{
Aldo Wicaksono Wibowo*, Nur Azizah, Primagita Fridayanti, Aang Afandi, Ludfi Djajanto \\ Masters in Applied Accounting Information Systems \\ Malang State Polytechnic \\ Malang, Indonesia \\ *wicaksonoaldo95@gmail.com
}

\begin{abstract}
The guidelines used in this study to design risk management for MSMEs. Café philosophy is the ISO 31000: 2009 standard. This study aims to plan the role of risk management to identify risks that can occur in business processes and to design and find out the processes and steps that must be taken by MSME Philosophy Café in managing risks in a systematic and planned manner. The case study was conducted at the MSME Philosophy Café. The data used are profile data and risk registers in Philosophy Café. Data was collected using the Forum Group Discussion (FGD) method by internal parties. From the analysis obtained states that the actions taken by the MSME Café philosophy are correct and appropriate because by taking these actions, can change the status level for the better and cause MSMEs to continue to grow. It can be concluded that the risk register contained in the MSMEs Philosophy Café is correct but must be improved again in order to get maximum results.
\end{abstract}

Keywords-ISO 31000, UMKM, risk register, forum group discussion

\section{INTRODUCTION}

Micro, Small and Medium Enterprises (MSMEs) play an important role in the Indonesian economy because they can become the spearhead of the national industry, and absorb a lot of labor. In the midst of globalization and high competition, it is necessary to empower MSMEs by making MSMEs able to face global challenges, things that can be done such as increasing product and service innovation, developing human resources and technology, as well as increasing the marketing area. These things can be done to increase the selling value of MSMEs, the most important thing is so that MSMEs can compete with foreign products that are increasingly flooding Indonesia's industrial and manufacturing centers, considering that MSMEs are the sector that is able to absorb the largest workforce in Indonesia [1].

This study was conducted on MSMEs engaged in the coffee industry, namely Filosofi Café, which is a family company that has been established for 4 years and is engaged in coffee roasting. The increasing demand for coffee roasting has made several sectors, especially production and distribution, quite overwhelmed. With this rapid business development,
Philosophy Café is currently trying to minimize the risks that exist in the business cycle that is carried out.

The philosophy of the Café is to run a business from upstream to downstream which is all about coffee and prioritizes high quality coffee. The biggest supply and demand for sangria coffee for Filosofi Café is currently in Kalimantan, Banjarmasin, Sumatra, Bima and various other major cities in Indonesia. Not only one type of roasted coffee is processed here, but the roasted coffee produced here is available with different variations of various types of Indonesian coffee and several variations of coffee imported from other countries such as Kenya, Brazil and Ethiopia.

MSME Philosophy Café, which is an MSME with definite goals, also has many risks and obstacles in achieving its goals. It is also necessary to implement and have risk management. As mentioned above, MSMEs must also be able to control existing risks and must be able to identify risks that may arise in the MSME business process. So that the MSME Philosophy Café also feels the need to implement risk management in their MSMEs. It is hoped that with the risk management design that can then be applied in the MSME Philosophy Café, it can reduce the impact and frequency of risk occurring within MSMEs. Risk management is expected to be able to help MSME Philosophy Café to achieve its goals more optimally by anticipating various kinds of risks that exist within the MSME Philosophy Café.

Research that discusses the application of risk management, Anton et al. [2] in this study describes the application of risk management in PT. Bank SulutGo is in accordance with the provisions of Bank Indonesia and the Financial Services Authority which of course fits the scope of the bank's business. This study shows that the corporate risk management variable (ERM) does not have a significant effect on firm value in the construction and property sectors [3]. And the results show that the application of ERM is still limited to following existing regulations and does not appear to have a direct impact on company value. Operational risk management carried out by BPRS Jabal Nur Tebuireng is carried out well [4]. This can be seen from the operational risk management carried out in accordance with the risk management process according to ISO 3100.There are differences in research results from risk 
management applied in various business sectors, so this study has the aim of identifying risks that can occur in business processes in MSMEs operating in the coffee sales sector is named Filosofi Café, as well as to design and know the process steps that must be taken by MSME Filosofi Café in managing risk in a systematic and planned manner.

Micro, Small and Medium Enterprises (MSMEs) According to the Law of the Government of the Republic of Indonesia number 20 of 2008, the Law on Micro, Small and Medium Enterprises, the definition of MSMEs is:

- Micro enterprises are productive businesses owned by individuals and / or individual business entities that meet the criteria for micro enterprises as regulated in this law.

- Small Business is a productive economic business that stands alone, which is carried out by an individual or business entity that is not a subsidiary or branch of a company that is owned, controlled, or is a part, either directly or indirectly, of a Medium or Large Business that meets the criteria of Small Business as referred to referred to in this Law.

- Medium Enterprises are productive economic enterprises that are independent, carried out by individuals or business entities that are not subsidiaries or branches of companies that are owned, controlled, or are part of, either directly or indirectly, with Small or Large Businesses with total net assets or annual sales proceeds as regulated in this Law.

\section{A. Risk}

Risk is defined as something that can create obstacles in achieving organizational goals, due to internal and external factors, depending on the type of risk that exists in a particular situation [5]. Risk is a series of challenges that must be faced. The characteristic of this challenge is that there is always a risk in every decision we make. Risk does not have a real form but is related to the direction we are going to achieve. This risk can affect us in achieving our goals. Risk can reduce our focus on success and stop us from achieving the results we want or the results we deserve [6].

\section{B. Definition of Risk Management}

According to Frinanda et al. [7], risk management is an effort to identify, analyze, and control risk in every company activity with the aim of obtaining higher effectiveness and efficiency. Risk management is an approach that adopts a consistent system to manage all risks faced by a company [8]. Gjerdum and Peter [9] defines corporate risk management as follows: "Enterprise risk management is a process, effect by an entity's board of directors, management and other personnel, applied in a strategy setting and across the enterprise, designed to identify potential that may affect the entity and manage risk to be within its risk appetite to provide reasonable assurance regarding the achievement of entity objectives. "The definition of ERM according to COSO is that corporate risk management is a process that is influenced by the board of directors, management and other personnel, implemented through a corporate-wide strategic setting and is designed to identify potential events that could affect the entity and manage risk with the aim of providing reasonable assurance in achieving the entity's objectives. Risk management, which is in accordance with the ISO 31000: 2009 standard, is a standard designed to provide general principles and guidelines in the application of risk management.

This International Standard provides for risk management principles, frameworks and processes. Risk management principles are the foundation of risk management frameworks and processes, while risk management frameworks are the building blocks for risk management processes. According to ISO 31000: 2009 Standard, the definition of risk is the impact of uncertainty on the achievement of objectives. The impact according to the ISO 31000 Standard is a deviation from what is expected, the bias is positive and / or negative. While the definition of risk management according to the ISO 31000 Standard is a coordinated activity to direct and control an organization in dealing with risks. ISO 31000: 2009 standards reveal that risk management an organization must follow 11 basic principles in order to be implemented effectively.

- Risk management creates added value (creates value)

- Risk management is an integral part of organizational processes (an integral part of organizational processes)

- Risk management is part of decision making (part of decision making)

- Risk management explicitly addresses uncertainty (explicitly addresses uncertainty)

- Risk management is systematic, structured and timely (systematic, structured and timely)

- Risk management based on the best available information (based on the best available information)

- Risk management tailored to your needs

- Risk management takes human and cultural factors into account (takes human and cultural factors into account)

- Risk management is transparent and inclusive (transparent and inclusive)

- Risk management is dynamic, interactive and responsive to change (dynamic, iterative and responsive to change)

- Risk management facilitates the improvement and continuous development of the organization (facilitates continual improvement and enhancement of the organization).

The risk management process is a critical activity in risk management, because it is an application of the principles and 
frameworks that have been built. The risk management process consists of 3 major processes, namely:

1) Establishing the context: Context setting aims to identify and disclose organizational goals that describe the environment of the objectives to be achieved, interested stakeholders, and the diversity of risk criteria, this will help reveal and assess the nature and complexity of risk. The risk management process is a critical activity in risk management. , because it is an application of the principles and frameworks that have been built.

2) Establishing the context: Context setting aims to identify and express organizational goals that describe the environment of the objectives to be achieved, interested stakeholders, and the diversity of risk criteria, these will help reveal and assess the nature and complexity of risk.

3) Risk assessment: Risk assessment consists of:

- Risk identification: identify any risks that can affect the achievement of organizational goals.

- Risk analysis: analyzing the likelihood and impact of identified risks.

- Risk evaluation: comparing the results of risk analysis with risk criteria to determine how risk treatment will be applied. The three major processes are accompanied by two processes, namely:

\section{Communication and Consultation}

Communication and consultation is important considering the ninth risk management principle demands transparent and inclusive risk management, where risk management must be carried out by all parts of the organization and takes into account the interests of all organizational stakeholders.

\section{Supervision and Review}

This section is needed to ensure that the implementation of risk management has gone according to the plan. The results of supervision and review can also be used as a consideration for making improvements to risk management.

\section{RESEARCH METHODS}

This writing uses descriptive qualitative and case study research methods. Data collection was carried out through a literature review on risk management design using ISO 310002009 standards which will be used in MSMEs, understanding and designing how the risk management process and risk management systematics are in ISO 31000-2009. A literature review was also conducted to learn about things that are necessary in MSMEs. Researchers also conducted a Focus Group Discussion (FGD) together with internal parties of the UMKM, namely 7 people (consisting of the head of UMKM, the head of UMKM operations, 2 employees of sales and marketing of MSME products, employees of the financial division, 2 production employees and also conduct participatory observations in SMEs to develop research results obtained to answer problems. Descriptive research is research that aims to obtain variable characteristics, which in this study is to obtain an overview of the risks that exist in the UMKM Philosophy Café and how to design risk management in the MSME Philosophy Café.

This research begins by collecting primary data and secondary data. Primary data was obtained through discussions by means of Forum Group Discussion (FGD) with internal parties of the MSME Philosophy Café, while secondary data was obtained directly from the MSME Philosophy Café. The steps in the research in more detail are:

- This research begins with carrying out data collection by using literature studies related to risk management design.

- Researchers conducted discussions in the form of FGDs to obtain data in order to design the MSME Philosophy Café risk management. This design is done in 7 steps, namely:

- setting context,

- risk identification,

- risk analysis,

- risk evaluation,

- risk management,

- $\quad$ supervision and review and

- communication and information.

- Measuring the risk maturity level (Risk Maturity Assessment) to see the differences before risk management planning and after risk management planning.

\section{RESEARCH RESULTS AND DISCUSSION}

The design of risk management at MSME Café philosophy includes stages;

- Determination of the context of the activities to be managed the risk,

- Risk identification,

- Risk analysis,

- Evaluation risk,

- Handling of risks,

- Supervision and Review,

- Communication and Consultation.

Of the seven risk management processes above, it is because the new MSME Philosophy Café will design and make risk management. Thus, the two final processes of risk management, namely supervision and review, communication 
and information cannot be implemented. This is because the risk management process has never been applied before at the MSME Philosophy Café. Therefore, the design of this risk management process can only be carried out at the stages of determining the context of the activities to be managed risk, risk identification, risk analysis, risk evaluation and risk management for MSME Filosofi Café.

\section{A. Determination of the Context of the Activities to be Managed the Risk}

Determination of context aims to identify and reveal organizational goals, the environment in which the goals are to be achieved, stakeholders who reveal and assess the nature and complexity of risks.

1) Risk management objectives: The objectives of risk management at the MSME Café philosophy are:

- Describe and detail the risks inherent in the UMKM Café philosophy,

- Manage the risks contained in the MSME Philosophy Café so that it can be minimized or an acceptable level.

- Providing learning in understanding risks in the tasks and activities of the MSME Philosophy Café)

- Providing input to the head of the MSME Philosophy Café regarding the benefits of risk management at the MSME Philosophy Café.

2) Scope of risk management: The scope of risk management includes how the implementation of risk management in the MSME Philosophy Café.UMK Philosophy Café as an organization, will use risk management with the following scope:
- Mapping the division of authority and responsibility for risk management.

- Provide direction in the application of risk management starting from identification, measurement, determination of response, implementation of control activities, communication and monitoring of risks.

- To serve as a guideline for the periodic development, communication and improvement of risk management policies and other supporting regulations in the field of risk management.

- Provide a clear picture to stakeholders on how MSMEs manage their business risks.

3) The goals: The goals of the MSME Cafe philosophy as an organization, of course, have goals to be achieved. So, in the next 5 (five) years, the following goals are to be achieved by the Café Philosophy MSMEs:

- UMKM Philosophy Café is able to sell Philosophy Café products as many as 250,000 pcs per year.

- Providing the best service to customers with quality products at competitive prices.

- Able to obtain permits from BPOM (Drug and Food Licensing Agency) and licensing from other agencies.

\section{B. Risk Status Change Report}

Reports used will be to show changes in risk that occur in the MSME Philosophy of the Café, after the company knows the risks that may occur and determines actions to deal with these risks. So that the MSME Philosophy Café can change the risk status by taking actions. See table 1 bellow.

TABLE I. REPORTS ON CHANGES IN RISK STATUS

\begin{tabular}{|c|c|c|c|c|c|c|c|c|c|}
\hline \multirow[t]{2}{*}{ NO. } & \multirow{2}{*}{$\begin{array}{c}\text { RISK } \\
\text { CODE }\end{array}$} & \multirow{2}{*}{$\begin{array}{c}\text { DESCRIPTION } \\
\text { OF RISK } \\
\text { EVENTS } \\
\end{array}$} & \multirow{2}{*}{$\begin{array}{c}\text { RISK MANAGEMENT } \\
\text { ACTION THAT HAS BEEN } \\
\text { COMPLETED }\end{array}$} & PROBABILITY & IMPACT & \multirow{2}{*}{$\begin{array}{l}\text { INITIAL } \\
\text { STATUS }\end{array}$} & PROBABILITY & IMPACT & \multirow{2}{*}{$\begin{array}{c}\text { END } \\
\text { STATUS }\end{array}$} \\
\hline & & & & \begin{tabular}{|c|}
$E A R L Y$ \\
\end{tabular} & $E A R L Y$ & & $E N D$ & $E N D$ & \\
\hline 1 & F-001 & $\begin{array}{l}\text { Products do not } \\
\text { suit consumer } \\
\text { desires }\end{array}$ & $\begin{array}{l}\text { 1. Providing allowances to } \\
\text { employees who attend training } \\
\text { 2. Issue certification 3. Give } \\
\text { bonuses to employees who sell } \\
\text { products according to target }\end{array}$ & $5=$ Very Big & $\begin{array}{l}4= \\
\text { Heavy }\end{array}$ & $\begin{array}{l}\text { EXTREME } \\
\text { HIGH }\end{array}$ & $4=$ Large & $\begin{array}{l}4 \quad= \\
\text { Heavy }\end{array}$ & $\begin{array}{l}\text { EXTRE } \\
\text { ME } \\
\text { HIGH }\end{array}$ \\
\hline 2 & $\mathrm{~F}-002$ & $\begin{array}{l}\text { Organizational } \\
\text { internal and } \\
\text { external } \\
\text { failures, system } \\
\text { failures }\end{array}$ & $\begin{array}{l}\text { 1. Providing allowances to } \\
\text { employees who attend training } \\
\text { 2. Issue certification } 3 \text {. Provide } \\
\text { bonuses to employees who sell } \\
\text { products according to target } 4 \text {. } \\
\text { Give awards for promotion for } \\
\text { work results }\end{array}$ & $2=$ Small & $\begin{array}{l}3 \quad= \\
\text { Medium }\end{array}$ & $\begin{array}{l}\text { MEDIUM } \\
\text { RISK }\end{array}$ & $2=$ Small & $\begin{array}{l}1 \\
\text { Very } \\
\text { light }\end{array}$ & $\begin{array}{l}\text { LOW } \\
\text { RISK }\end{array}$ \\
\hline 3 & F-003 & $\begin{array}{l}\text { Product } \\
\text { marketing } \\
\text { failure }\end{array}$ & $\begin{array}{l}\text { 1. Using some social media to } \\
\text { attract customer interest } 2 . \\
\text { Maximizing Facebook Ads }\end{array}$ & $2=$ Small & $\begin{array}{l}3 \quad= \\
\text { Medium }\end{array}$ & $\begin{array}{l}\text { MEDIUM } \\
\text { RISK }\end{array}$ & $2=$ Small & $\begin{array}{l}1 \\
\text { Very } \\
\text { light }\end{array}$ & $\begin{array}{l}\text { LOW } \\
\text { RISK }\end{array}$ \\
\hline 4 & F-004 & Failed & 1. Improve stock management & $2=$ Small & $\begin{array}{l}3= \\
\text { Medium }\end{array}$ & $\begin{array}{l}\text { MEDIUM } \\
\text { RISK }\end{array}$ & $1=$ Very Small & $\begin{array}{l}2= \\
\text { Light }\end{array}$ & $\begin{array}{l}\text { LOW } \\
\text { RISK }\end{array}$ \\
\hline 5 & F-005 & $\begin{array}{l}\text { Financial } \\
\text { management } \\
\text { failure / } \\
\text { recording error }\end{array}$ & $\begin{array}{l}\text { 1. A verification audit must be } \\
\text { carried out }\end{array}$ & $3=$ Medium & $\begin{array}{l}3 \quad= \\
\text { Medium }\end{array}$ & $\begin{array}{l}\text { HIGH } \\
\text { RISK }\end{array}$ & $2=$ Small & $\begin{array}{l}2 \\
\text { Light }\end{array}$ & $\begin{array}{l}\text { MEDIU } \\
\text { M RISK }\end{array}$ \\
\hline
\end{tabular}


Description of the Division on Café Philosophy:

F-001: Sales

F-002: Operational

F-003: Digital Marketing

F-004: Production

F-005: Finance

\section{Risk Level Criteria}

The risk level criteria described from the previous matrix will then determine what actions will be taken at this stage. For a low level of risk, it is stated that there is no need to take any action because the risk is still accepted. This action is obtained from the results determined by the internal party of the MSME Philosophy Café. So, each level has considered what steps need to be taken in order to deal with the risks that occur.

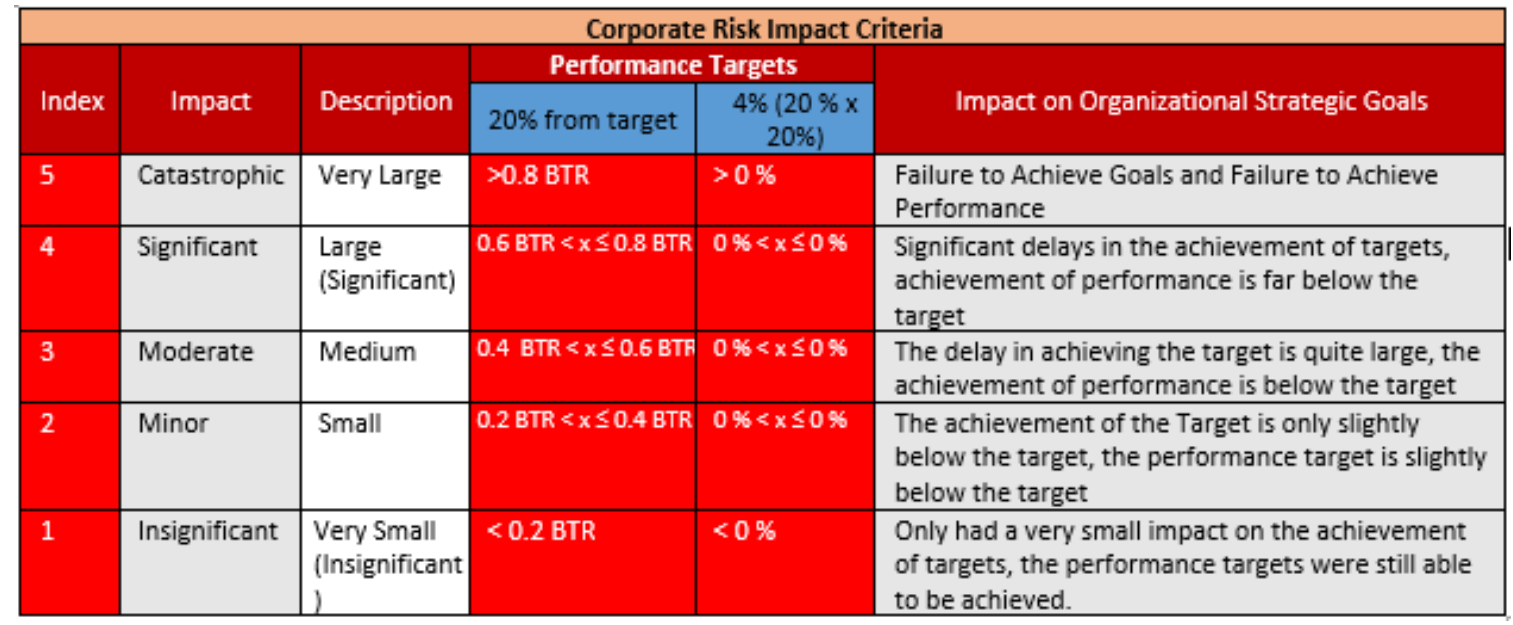

Fig. 1. Criteria for risk impact.

Similar research that examines the application of risk management principles [10]. All of the most impactful and high-level risks are the risk of decreasing income, decreasing production volume and increasing raw material prices and the risk that has a low level is late delivery of raw materials. Managing the risk of increasing income by re-planning income such as sorting out the budget that is the main priority and making financial adjustments. Sari et al. [11] has the results at the risk identification stage in the small rattan industry in Malang city produced 3 main risk factors, namely supply risk (supply chain), marketing risk, and operational risk. In the risk assessment process, supply risk and marketing risk are in the red zone (high) so that it needs special attention, while operational risk is in the yellow zone (minor) which has little effect.

From the results of the MSME Filosofi Café risk register analysis, it can be seen from the tables and figures that in each division there are risks that can occur, namely: The risk selling division is the product not according to consumer wishes, there is a risk of internal and external failure of the organization's system failure is in the operational division, at the digital marketing division fails to market products, while in the production division there is a risk of product failure, and in the financial division there is a risk of financial management failure or recording errors. However, from the risks that occur, there are fairly good handlers carried out by the company so that the change in risk status is getting better.

\section{CONCLUSIONS AND SUGGeSTIONS}

There are 5 risks in the MSME Philosophy Café. These risks are risks that occur because they are considered to be obstacles in achieving the goals of the MSME Café philosophy. Of the 5 risks contained in the MSME Café philosophy, it consists of 1 sales risk, 1 operational risk, 1 digital marketing risk, 1 production risk and 1 financial risk. These risks are products not according to consumer desires, internal and external failure of the organization, system failure, product marketing failure, product failure, financial management failure / recording error. From the risks that occur Philosophy Café has taken the right actions so as to change the level of risk.

With all these risks, a written and formal risk management is created to be applied to the MSME Philosophy Café. This risk management design consists of 7 stages of the process, namely, the process of determining the context, the process of risk identification, the process of risk analysis, the process of risk evaluation, the process of risk control and the last two processes that cannot be implemented in the MSME Philosophy Café, namely, the process of monitoring, reviewing, communication, and information.

The risk management advice that is designed is decided to become a formal and written standard in the café's MSME philosophy. So, if these risks occur, the MSMEs already have efforts to deal with or at least be able to minimize the occurrence of these risks. In addition, the policies that can be 
implemented by the Café Philosophy MSME can maximize the application of risk management. These policies are related to who is in charge of managing the risk management process, managing the risk register and how the process of risk management oversight in MSMEs.

\section{REFERENCES}

[1] R. Sudayanto, Ragimun, and Rahma, Starategi empowering MSMEs to face the ASEAN free market. Univ. Jember State, 2011.

[2] L.S. Antou, P. Tommy, and J.E. Tulung, "Penerapan Manajemen Risiko Pada Pt. Bank Sulutgo," Jurnal EMBA: Jurnal Riset Ekonomi, Manajemen, Bisnis dan Akuntansi, vol. 6, no. 3, 2018.

[3] O. Aditya and P. Naomi, "Implementation of Corporate Risk Management and Company Value in the Construction and Property Sector," The Essence of J. Business and Management., vol. 7, no. 2, pp. 167-180, 2017.

[4] W.R.S. Jelita and A. Shofawati, "Operational Risk Management at PT Bank Syariah Rakyat (BPRS) Jabal Nur Tebuireng in Surabaya," Falah J. Ekon. Sharia, vol. 4, no. 1, p. 69, 2019.
[5] N. Kusumawati, A. Halim, and Retno Wulandari, "The Role of Internal Audit in Realizing Good Corporate Governance (Study on Regional Drinking Water Companies (PDAM) Blitar Regency)," J. Ris. Mhs. Account. Unikama, 2016.

[6] Karinov, "Business Feasibility Study: Its Goals and Benefits," [Online]. Retrieved from karinov.co.id

[7] R.A. Frinanda, I. Hadipranoto, and M. Salsabiela, "Hazard Risk Analysis and Building Risk Management at PT Angkasa Pura II (Persero) Tangerang Main Branch Office," J. Migration, 2017.

[8] Supriyati and B. Tjahjadi, "Corporate social responsibility and financial performance: Stakeholder theory vs good management theory," Int. J. Econ. Res., 2017.

[9] D. Gjerdrum and M. Peter, "The New International Standard on the Practice of Risk Management - A Comparison of ISO 31000: 2009 and the COSO ERM Framework," Risk Manag., 2011.

[10] I. Safi'i, S.R. Widodo, and R.L. Pangastuti, "Analysis of the Risk of Tofu Takwa Kediri UKM on the Impact of the COVID-19 Pandemic," J. Engineering System. Ind., vol. 9, no. 2, pp. 107-114, 2020.

[11] R.A. Sari, R. Yuniarti, and D. Puspita, "Analisa manajemen risiko pada industri kecil rotan di Kota Malang," Journal of Industrial Engineering Management, vol. 2, no. 2, pp. 39-47, 2017. 